\title{
USING HEC-RAS SOFTWARE TO ANALYZE 6 PARAMETERS REGARDING THE MANIFESTATION OF FLOOD EVENTS. A CASE STUDY OF BASEU RIVER LOWLAND, NE ROMANIA
}

DOI: http://dx.doi.org/10.18509/GBP.2019.75

UDC: 551.311.2:[528.004.4(498)

\author{
Andrei Urzică ${ }^{1}$ \\ Alin Mihu-Pintilie ${ }^{2}$ \\ Elena Huțanu ${ }^{1}$ \\ Cristian Constantin Stoleriu ${ }^{1}$ \\ ${ }^{1}$ Department of Geography, Faculty of Geography and Geology, \\ Alexandru Ioan Cuza University of Iasi, Iasi, Romania \\ ${ }^{2}$ Institute for Interdisciplinary Research, Science Research Department, \\ Alexandru Ioan Cuza University of Iasi, Iasi, Romania
}

\begin{abstract}
Floods continuously affect an impressive number of communities, both on a global scale and on a regional scale. Studying and understanding this phenomenon through management decisions can significantly reduce the damage that this kind of phenomenon can cause on natural communities and territories. Starting from this premise, the European Parliament implemented on October 23, 2007 the 2007/60 EC Directive, which requires Member States to create hazard maps and flood risk maps, and on the basis of these maps to implement the flood risk management plan for each river basin. This Directive provides that the management plans should be done at the level of basins and sub-basins, but does not mention the rank to which such a plan should be developed, which may endanger certain communities located on the course of small rivers. The Başeu river basin is administratively part of the Prut-Barlad hydrographic area. Although the Prut-Barlad hydrographic area has a management plan, it was made only for the main rivers, the Baseu river being excluded. The present study aims to analyze 6 important parameters for understanding the flood events (depth, velocity, shear stress, arrival time, duration and recession) and the development of hydrological risk maps.
\end{abstract}

Keywords: HEC-RAS, velocity, shear stress, depth, arrival time, duration, recession

\section{INTRODUCTION}

Globally, floods cause the greatest damage, both directly and indirectly. Out of the two categories, direct damage has a major impact on human society, and is due to the actual destruction caused by floods (destroying dams, damaging or completely destroying roads, damaging farm crops, buildings, human losses or illnesses etc.). Indirect damages are caused by the effect of the phenomenon produced on society over time (rising food prices, interruption of communication channels and economic activities etc.) [1-6].

The occurrence of extreme hydrological phenomena such as floods has intensified in recent decades, both due to climate change and uncontrolled deforestation at global, regional and local levels. The increase in number of the catastrophic hydrological events is also due to accelerated urbanization by building in the major riverbed. In Romania, floods can occur in all four seasons. In the spring, the floods can occur due to positive temperatures, fact that leads to the melting of ice and snow, due to heavy and long-lasting 
rainfall, or by combining the two of them, melting ice and snow overlaid with high rainfall. In summer and fall, floods' main cause is the heavy rainfall that occurs on a short period of time. The amount of water exceeds soil retention capacity and, in the absence of wooden surfaces, can cause the movement of a large amount of parental material by erosion. In winter, the floods are caused by the sudden melting of snow on the basis of rising temperatures. The soil retention capacity is low due to frost or can reach a maximum value, which leads to the generation of flash floods.

Floods are part of the progressive hazards category due to the possibility of human intervention at the time of production, by taking decisions such as evacuating the areas at risk of being affected or providing financial support to areas that have already been affected by the phenomenon. Studying and understanding how this phenomenon manifest can lead to better water resource management, but also to better manage flood risk by preventing and mitigating the effects it can have on human communities. In this regard, the European Parliament adopted in 2007 Directive 2007/60/EC, which stipulates the realization and implementation of management plans for each river basin in order to protect and reduce the negative effects on human health and economic activities [7,8]. The present study aims to provide a methodology and cartographic materials that can lead to the implementation of flood management plans for river basins that have never had such plans implemented. The analysis of some parameters such as depth, velocity, shear stress, arrival time, duration and recession provides an overview of how a flood is displayed depending on the geographical area, geological, pedological and geomorphological conditions. Based on these, decisions can be taken more easily to protect flood risk areas [9-13].

The Baseu hydrographical basin is part of the Prut-Barlad hydrographic area, which is under the administration of Prut-Barlad Water Basin Administration. The Prut-Barlad hydrographic area already has a flood management plan, but it only covers the major rivers that are under its management. The Baseu river basin together with many other river basins of same size or smaller, are yet to have a management plan. The lack of a management plan for such important hydrographic arteries at local level affects and will continue to affect the socio-economic activities of the surrounding area.

In the case of Baseu hydrographic basin, negative hydrological events occurred over time, but a management plan is still missing. The hydrological events of 1932, 1941, 1955, 1965, 1985, 1969, 2005, 2008 are among the most important events that took place on the Baseu River. The 1969 flood was the strongest event in its history, with a maximum flow of $330 \mathrm{~m}^{3} / \mathrm{s}$ which affected the localities in the surrounding area.

\section{STUDY AREA}

Baseu river basin is located in the North-Eastern part of Romania, in the Moldavian Plain (Figure 1). It has an area of $967 \mathrm{~km}^{2}$, while the length of the river is $118 \mathrm{~km}$. The surface and the length of the river make this hydrographical artery one of the most important in the Moldavian Plain. Within the limits of Baseu river basin there are 54 localities with a total population of approximately 80,000 inhabitants, but only 30 localities are located near the river. The population of the 30 localities that are located near the river and being at risk of flood occurrence is about 37,000 .

In the lower course of the Baseu river there are 5 localities, 4 of them on the right side of the river (Ștefănești, Bădiuţi, Bobulești, Românești) and only one on the left (Stânca). The population of the five localities totals about 8,000 inhabitants, of which $27 \%$ are part of the administrative unit of Românești, and the rest of $73 \%$ of the administrative unit of 
Ștefannești. The length of the analyzed river sector is $14.8 \mathrm{~km}(12.5 \%$ of the total length of the river), and the area is $58 \mathrm{~km}^{2}$ (6.3\% of the Baseu river basin). The average slope is 2.7, while the average altitude is $63.5 \mathrm{~m}$ on the course of the river. The maximum altitude in the study area is $165 \mathrm{~m}$, the minimum of $54.4 \mathrm{~m}$. The analyzed sector is framed in the following geographic coordinates: 47 $50^{\prime}$ lat. $\mathrm{N} ; 4^{\circ} 42^{\prime} 55^{\prime \prime}$ lat. $\mathrm{N} ; 2^{\circ} 8^{\prime} 25^{\prime \prime}$ long. E; $27^{\circ} 11$ '35" long. E.

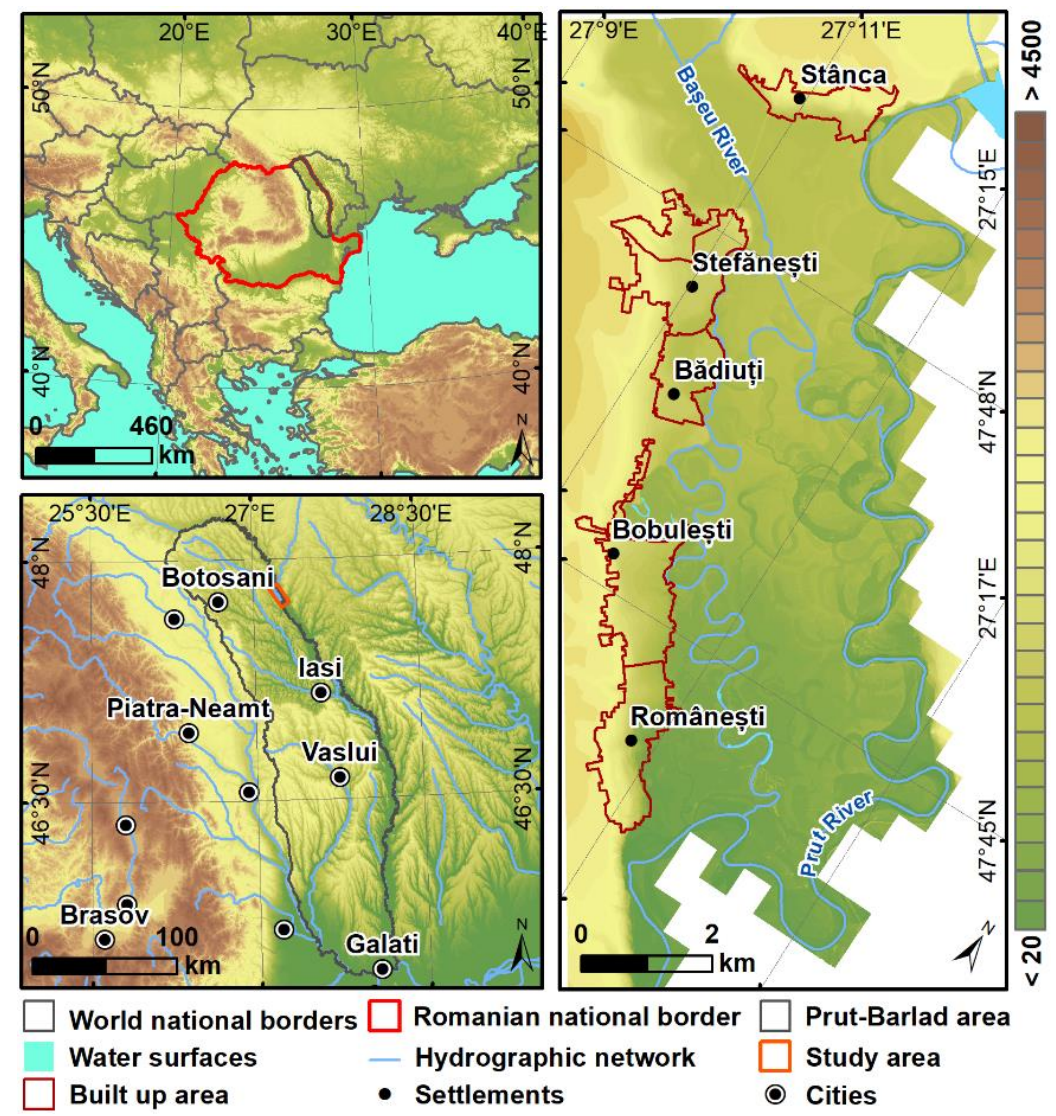

Figure 1. Geographical location of the Baseu river lowland

\section{METHODS}

Making hydrological risk maps involves knowing the topographic area at a very detailed level in order to be able to take into account the morphology analysis of the study area. The need for a detailed Digital Elevation Model (DEM) is imperative. For the present study, a DEM with a spatial resolution of $1 \mathrm{~m} /$ pixel (LiDAR) was used, the spatial resolution giving an overview of all the relief microforms present in the analyzed area. The analysis based on DEM from the LiDAR dataset was made possible thanks to PrutBarlad Water Basin Administration, institution which provided the dataset containing the DEM's tiles in .tif format [14].

Thus, to generate the DEM that was introduced into hydrological modeling, it was necessary to merge the tif files to generate a compact DEM, after which the buildings present in the study area were digitized. The need for building digitization derives from the impact that such structures has on the leakage of water. For each polygon representing a building, it has been given a $6 \mathrm{~m}$ altitude and it was converted to raster format, based on its height. The final step was to add the new raster to the previously created DEM from the .tif files (Figure 2). 


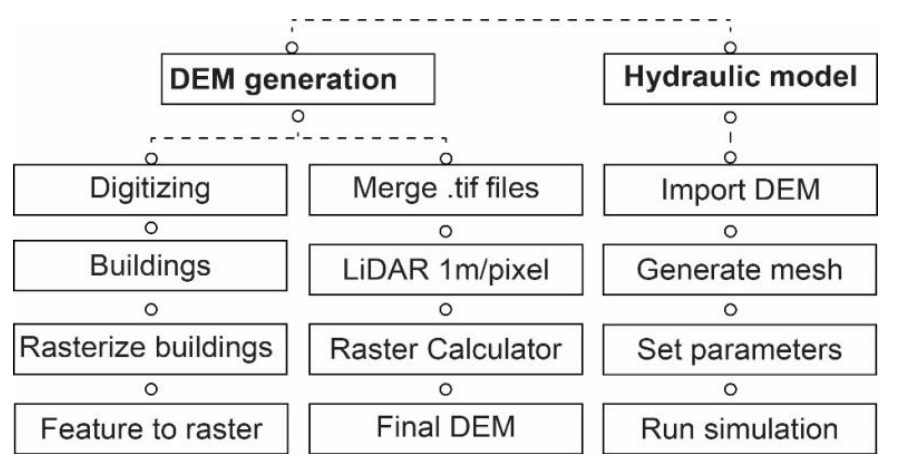

Figure 2. Methodological workflow for the generation of a DEM based on LiDAR dataset and a hydraulic model using HEC-RAS software

The HEC-RAS software, v. 5.0.5, 2D water modeling module, was used to achieve the hydraulic model. The study area was outlined, a mesh of 7930 cells was generated, with a mean cell surface of $936.5 \mathrm{~m}^{2}$. Manning's $\mathrm{n}$ roughness was set to 0.030 . A boundary conditions of an input and an output were needed. Thus, for the input the flow hydrograph was set as boundary condition, while for the output it was set as normal depth. The simulation was run as an unsteady flow analysis and as a result there have been generated the values for depth, velocity, shear stress, arrival time, duration and recession.

\section{RESULTS AND DISCUSSION}

By analyzing the cartographic materials, one can see that the morphology plays a very important role in reaching the maximum flow of a river. Five of six parameters (arrival time, flood depth, duration, velocity, shear stress), have higher values in the riverbeds (Başeu and Prut river), in the abandoned meanders areas or where channels were built for irrigation. Regarding the sixth parameter, recession time, it presents high values (98 hours) across the entire study area, with small areas where the water withdrawal time drops to 45 hours.

Table 1. Values of the affected surfaces according to the arrival time of the flood

\begin{tabular}{lccccccc}
\hline Classes (hrs) & $\mathbf{0 ~ - ~ 8}$ & $\mathbf{8 - 2 4}$ & $\mathbf{2 4 - 3 8}$ & $\mathbf{3 8 - 5 2}$ & $\mathbf{5 2}-\mathbf{6 8}$ & $\mathbf{6 8}-\mathbf{8 2}$ & $\mathbf{8 2}-\mathbf{9 8}$ \\
\hline Surface (ha) & 495.9 & 494.8 & 510.6 & 643.7 & 380.5 & 283.7 & 287.6 \\
Percent (\%) & 16.0 & 16.0 & 16.5 & 20.8 & 12.3 & 9.2 & 9.3 \\
\hline
\end{tabular}

Knowing the arrival time of the flood wave is very important for the flood defense plans because decisions can be made in order to protect the communities (Figure 3a). Also, knowing the time of withdrawal of the water after the maximum leakage can lead to making decisions as to when it will be able to penetrate the affected perimeter in order to assess the damage, rebuild damaged or destroyed objects (Figure 3b).

Table 2. Values of the affected surfaces according to the recession time of the flood

\begin{tabular}{lcccc}
\hline Classes (hrs) & $\mathbf{4 5 - 5 2}$ & $\mathbf{5 1 - 8 5}$ & $\mathbf{8 5 - 9 7}$ & $\mathbf{9 7 - 9 8}$ \\
\hline Surface (ha) & 0.4 & 1.7 & 1.5 & 3093.0 \\
Percent (\%) & 0.01 & 0.06 & 0.05 & 99.88 \\
\hline
\end{tabular}

Also, the descriptive and statistical situations of each parameter can be extracted depending on the area it covers. Thus, for the time of arrival of the flood wave, they were extracted on the basis of the classes. The largest area (643,7 ha) will be covered in a time 
of 38 - 52 hours (Table 1). Over $99 \%$ of the flooded area will withdraw its waters in $97-$ 98 hours (Table 2).

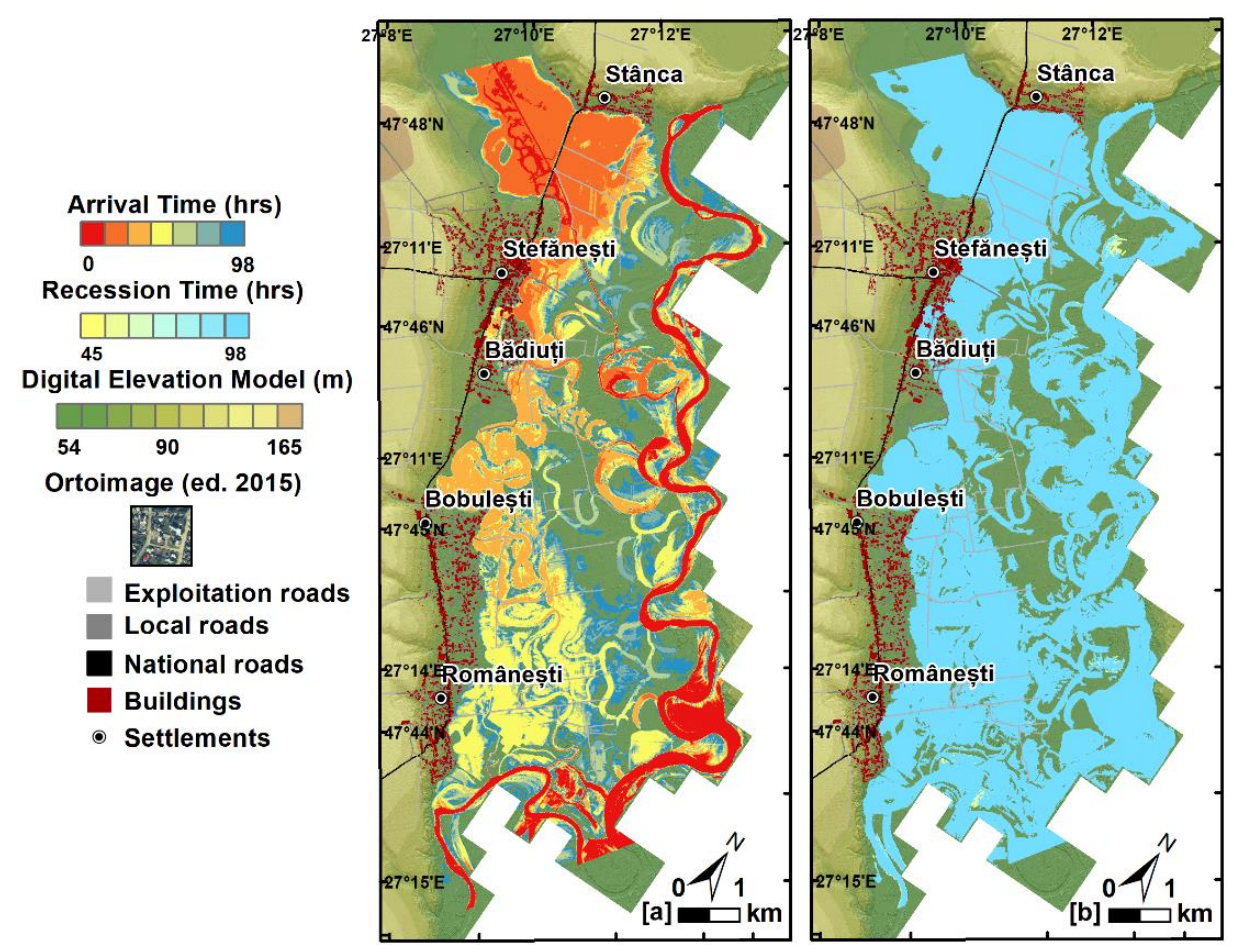

Figure 3. The arrival time (3a) and recession time (3b) of the flood

The flood depth (Figure 4a) represents the flood volume related to the surface taken in the analysis and provides information on the thickness of the water layer. Information on the depth of the water column can be used to organize response actions of authorities and populations during the hydrological phenomenon, or to achieve structural protection measures such as dams, transverse or lateral accumulations for prevention and flood protection. Duration time represents the number of hours in which water depth exceeds the normal flow rate (Figure $4 b$ ).

Table 3. Values of the affected surfaces according to the flood depth

\begin{tabular}{lccccccc}
\hline Classes (m) & $\mathbf{0 - 0 . 5}$ & $\mathbf{0 . 5} \mathbf{- 1}$ & $\mathbf{1 - 1 . 5}$ & $\mathbf{1 . 5}-\mathbf{2 . 7}$ & $\mathbf{2 . 7}-\mathbf{4}$ & $\mathbf{4 - 5 . 2}$ & $\mathbf{5 . 2}-\mathbf{6 . 1}$ \\
\hline Surface (ha) & 1040.2 & 816.1 & 722.3 & 228.1 & 78.9 & 164.7 & 46.4 \\
Percent (\%) & 33.6 & 26.4 & 23.3 & 7.4 & 2.5 & 5.3 & 1.5 \\
\hline
\end{tabular}

As for the areas covered by different levels of water, an area of 1040.2 ha is covered by a depth of 0 to $0.5 \mathrm{~m}$ and the highest depths cover an area of 46.4 ha (Table 3 ). The duration of 86 to 98 hours covers the largest area, 692.6 ha, representing $22.4 \%$ of the affected area. The small duration, ranging from 0 to 11 hours, covers an area of 188.4 ha $(6.1 \%)$ (Table 4).

Table 4. Values of the affected surfaces according to the duration time of the flood

\begin{tabular}{cccccccc}
\hline Classes (hrs) & $\mathbf{0 ~ - ~ 1 1}$ & $\mathbf{1 1 - 2 6}$ & $\mathbf{2 6 - 4 0}$ & $\mathbf{4 0}-\mathbf{5 4}$ & $\mathbf{5 4 - 6 8}$ & $\mathbf{6 8}-\mathbf{8 6}$ & $\mathbf{8 6}-\mathbf{9 8}$ \\
\hline Surface (ha) & 188.4 & 251.1 & 321.4 & 400.2 & 659.9 & 583.1 & 692.6 \\
Percent (\%) & 6.1 & 8.1 & 10.4 & 12.9 & 21.3 & 18.8 & 22.4 \\
\hline
\end{tabular}

Flood wave propagation velocities are greatly influenced by the roughness of the area. Knowing the speed of the flood wave can influence future decisions about possible 
landscaping of areas with different roughness values, such as the arrangement of some (with a high roughness) plantations of trees seeking to reduce the speed of the flood wave. Also, knowing the speed helps to create a plan to protect areas with very high erosion potential, thus diminishing the impact that floods have on morphology (Figure 5a). The last parameter calculated, a very important one, the shear stress is manifested by all kind of erosion on the topographic surface. These processes have a higher or lower impact on the land surface, depending on the geological substrate (Figure 5b)

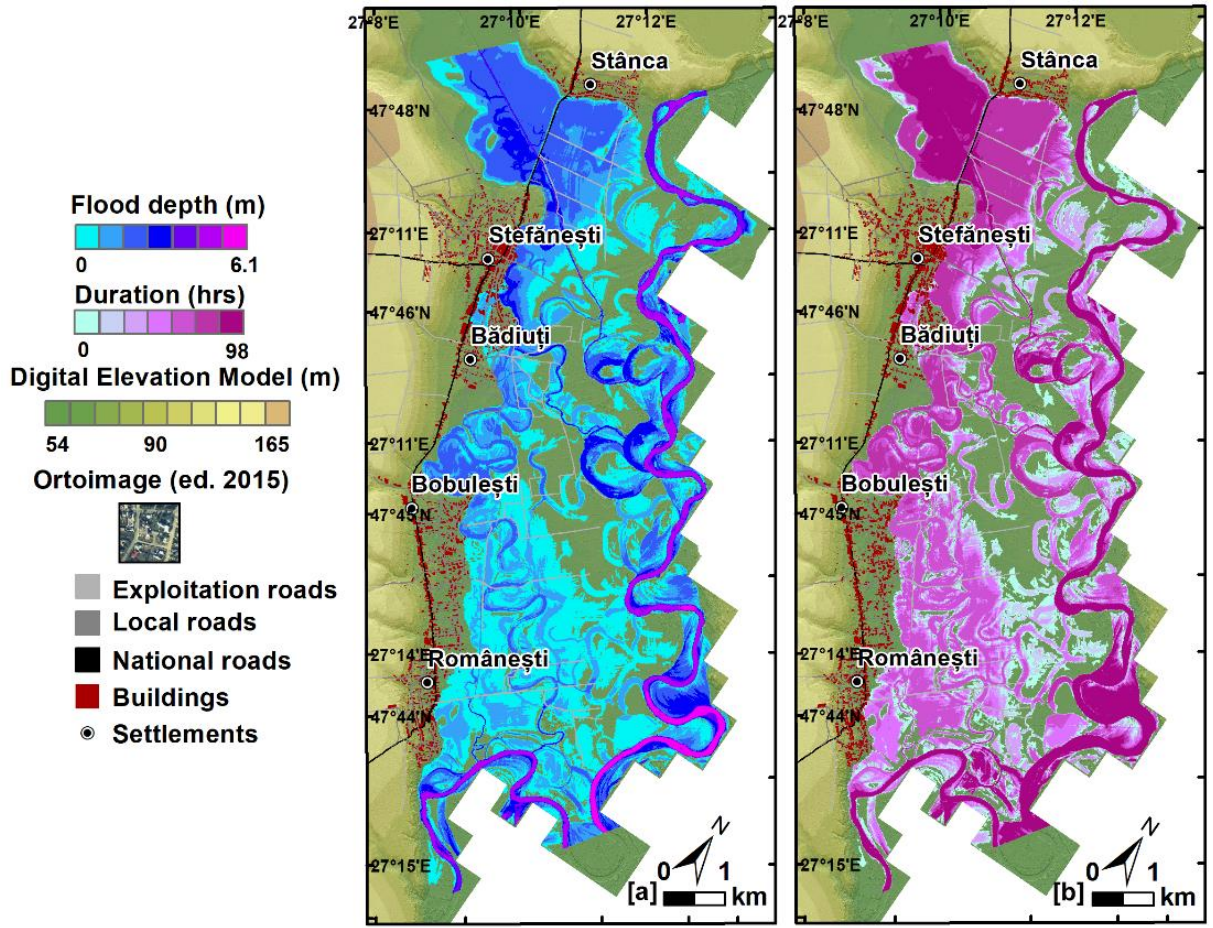

Figure 4. The flood depth (4a) and the duration time (4b) of the flood

Speeds ranging from 0.2 to $0.4 \mathrm{~m} / \mathrm{s}$ affect a total area of 1216.4 ha $(39.3 \%)$ and are specific to the area between Bădiuţi and Românești localities. The highest speeds (2.7 $5.1 \mathrm{~m} / \mathrm{s})$ affect an area of 1.1 ha $(0.04 \%)$ and are specific to the confluence area of the Başeu River with the Prut River (Table 5).

Table 5. Values of the affected surfaces according to the velocity of the flood

\begin{tabular}{lccccccc}
\hline Classes (m/s) & $\mathbf{0 - 0 . 2}$ & $\mathbf{0 . 2}-\mathbf{0 . 4}$ & $\mathbf{0 . 4 - 0 . 6}$ & $\mathbf{0 . 6 - 0 . 9}$ & $\mathbf{0 . 9}-\mathbf{1 . 6}$ & $\mathbf{1 . 6}-\mathbf{2 . 7}$ & $\mathbf{2 . 7}-\mathbf{5 . 1}$ \\
\hline Surface (ha) & 892.4 & 1216.4 & 649.1 & 269.2 & 62.3 & 6.2 & 1.1 \\
Percent (\%) & 28.8 & 39.3 & 21.0 & 8.7 & 2.0 & 0.2 & 0.04 \\
\hline
\end{tabular}

Potential erosion with values ranging from $0-0.01 \mathrm{~kg} / \mathrm{m}^{2}$ affects an area of $1684.2 \mathrm{ha}$ $(54.4 \%)$ and is specific to flat areas. The highest values, $0.24-0.5 \mathrm{~kg} / \mathrm{m} 2 \mathrm{~kg} / \mathrm{m}^{2}$, affect an area of 3.9 ha $(0.1 \%)$ and are specific to the areas where the drainage channel narrows down (Table 6).

Table 6. Values of the affected surfaces according to the shear stress of the flood

\begin{tabular}{lccccccc}
\hline \multirow{2}{*}{ Classes $\left(\mathbf{k g} / \mathbf{m}^{2}\right)$} & $\mathbf{0}$ & $\mathbf{0 . 0 1}$ & $\mathbf{0 . 0 2}$ & $\mathbf{0 . 0 5}$ & $\mathbf{0 . 0 8}$ & $\mathbf{0 . 1 5}$ & $\mathbf{0 . 2 4}$ \\
& $\mathbf{0 . 0 1}$ & $\mathbf{0 . 0 2}$ & $\mathbf{0 . 0 5}$ & $\mathbf{0 . 0 9}$ & $\mathbf{0 . 1 5}$ & $\mathbf{0 . 2 4}$ & $\mathbf{0 . 5}$ \\
\hline Surface $(\mathbf{h a})$ & 1684.2 & 926.1 & 337.1 & 97.4 & 35.9 & 12.2 & 3.9 \\
Percent $(\boldsymbol{\%})$ & 54.4 & 29.9 & 10.9 & 3.1 & 1.2 & 0.4 & 0.1 \\
\hline
\end{tabular}




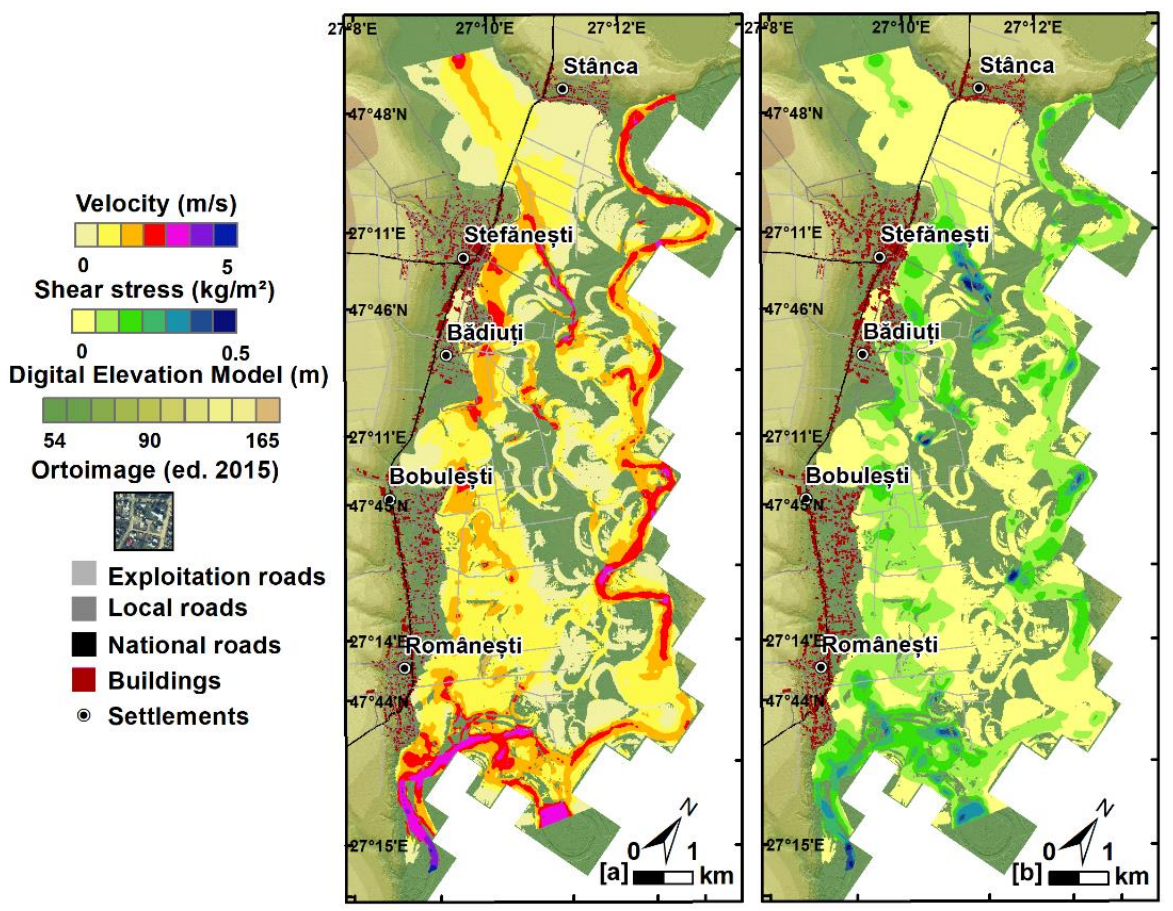

Figure 5. The velocity (5a) and the shear stress $(\mathbf{5 b})$ of the flood

\section{CONCLUSIONS}

This study sought to analyze 6 important flood parameters and thus the flood itself. The study area is represented by the Başeu river basin, case study on the Baseu river lowland, the common floodplain of the Başeu and Prut rivers. Based on a $1 \mathrm{~m} /$ pixel spatial resolution DEM and the HEC-RAS hydraulic modeling software, parameters such as depth, velocity, shear stress, arrival time, duration and recession were analyzed. The analysis was carried out for a surface of $58 \mathrm{~km}^{2}$, representing $6.3 \%$ of the entire area of the hydrographic basin. The results show that the same methodology can be applied to small, medium or large river basins, and the results obtained can be integrated into the flood risk management plans.

\section{ACKNOWLEDGMENT}

This work was funded by the Ministry of Research and Innovation within Program 1 Development of the national RD system, Subprogram 1.2 - Institutional Performance RDI excellence funding projects, Contract no.34PFE/19.10.2018 (beneficiary: Alin Mihu-Pintilie). Also, our thanks go to the Head of Geoarchaeology Laboratory within the Faculty of Geography and Geology, Department of Geography, "Alexandru Ioan Cuza" University of Iasi - Romania, which provided the equipment for data processing.

\section{REFERENCES}

[1] Romanescu G. \& Stoleriu C.C. Exceptional floods in the Prut basin, Romania, in the context of heavy rains in the summer of 2010, Natural Hazards and Earth System Sciences, Germany, vol. 17, pp. 381-396, 2017;

[2] Romanescu G. \& Stoleriu C.C. Causes and effects of the catastrophic flooding on the Siret River (Romania) in July-August 2008, Natural Hazards, Netherlands, vol. 63, pp. 1351-1367, 2013; 
[3] Romanescu G., Stoleriu C.C. \& Romanescu A.M. Water reservoirs and the risk of accidental flood occurrence. Case study: Stanca-Costeşti reservoir and the historical floods of the Prut river in the period July-August 2008, Romania, Hydrological Processes, United States, vol. 25, pp. 2056-2070, 2011;

[4] Paveluc L., Cojoc G. \& Tirnovan A. The water resources in the Trebes-Negel hydrographic basin (Romania), Geobalcanica 4th International Scientific Conference, Republic of Macedonia, 2018, pp. $31-38$;

[5] Enea A., Urzica A. \& Breaban I.G. Remote Sensing, GIS and HEC-RAS techniques, applied for flood extent validation, based on Landsat Imagery, LiDAR and hydrological data. Case study: Baseu River, Romania, J Environ. Prot. Ecol, vol. 19, pp. 1091-1101, 2018;

[6] Kalikci T., Kusztal P., Nowak M. \& Zaborska D. Structure and age of terraces and flood plains: case study from the Czarna Konecka (Holy Cross Mountains - polish uplands), Geobalcanica 4th International Scientific Conference, Republic of Macedonia, 2018, pp. 111 118 ;

[7] Directive 2007/60/EC of the European Parliament and of the Council of 23 Octomber 2007;

[8] Zlatinova D. Integrating flood risk assessment into management practice (case study in Bulgaria), Geobalcanica 4th International Scientific Conference, Republic of Macedonia, 2018, pp. $505-512$;

[9] Ghindaoanu V.B., Hutanu E. \& Urzica A. The GIS modeling of the terrain favorability for the placement of constructions in the areas with hydro-geomorphological risk, Geobalcanica 4th International Scientific Conference, 2018, Republic of Macedonia, pp. 22 - 30;

[10] Hutanu E., Mihu-Pintilie A. \& Urzica A. The use of GIS techniques for obtaining potentially floodable surfaces in the jijia floodplain, Geobalcanica 4th International Scientific Conference, 2018, Republic of Macedonia, pp. 473 - 480;

[11] Hutanu E., Urzica A. \& Enea A. Evaluation of damages caused by flood, based on satellite images. Case study: Jijia River, Slobozia-Dângeni Sector, July 2010", Present Environment and Sustainable Development Conference, Romania, 2018, pp. 135-146;

[12] Romanescu G., Cimpianu C.I., Mihu-Pintilie A. \& Stoleriu C.C. Historic flood events in NE Romania (post-1990), Journal of Maps, Romania, pp 787-798, 2017.

[13] Romanescu G., Mihu-Pintilie A., Stoleriu C.C., Carboni D., Paveluc L.E. \& Cimpianu C.I. A Comparative Analysis of Exceptional Flood Events in the Context of Heavy Rains in the Summer of 2010: Siret Basin (NE Romania) Case Study. Water, Romania, pp 1-17, 2018.

[14] Urzica A., Mihu-Pintilie A, Hutanu E, Ghindaoanu V.B. \& Albu L.M. Using GIS methods for modelling exceptional flood events in Baseu river basin, NE Romania, Geobalcanica 4th International Scientific Conference, 2018, Republic of Macedonia, pp. $463-471$. 